\title{
Monastic Musical Fragments from Iceland
}

\author{
Gisela Attinger
}

check for

updates

Citation: Attinger, Gisela. 2021. Monastic Musical Fragments from Iceland. Religions 12: 416. https:// doi.org/10.3390/rel12060416

Academic Editor:

Steinunn Kristjánsdóttir

Received: 28 April 2021

Accepted: 2 June 2021

Published: 7 June 2021

Publisher's Note: MDPI stays neutral with regard to jurisdictional claims in published maps and institutional affiliations.

Copyright: (C) 2021 by the author. Licensee MDPI, Basel, Switzerland. This article is an open access article distributed under the terms and conditions of the Creative Commons Attribution (CC BY) license (https:// creativecommons.org/licenses/by/ $4.0 /)$.
Humanities and Social Sciences Library, University of Oslo, 0315 Oslo, Norway; gisela.attinger@ub.uio.no

Abstract: Little has survived from medieval liturgical books in the Nordic countries other than fragments. It is often difficult, if not impossible, to state their exact provenance, but the contents sometimes indicate that they once belonged to a monastic institution. The article presents some of these sources, focusing on two fragments with music for the celebration of St Olav from Iceland and Sweden which show how an already established sequence of songs was adapted to fit the liturgical needs of a monastic community. In addition, it briefly presents two other Icelandic sources that follow monastic use and can shed more light on musical traditions in the Icelandic monasteries in the Middle Ages.

Keywords: liturgical music; monastic institutions; St Olav; Iceland; Sweden; Middle Ages

\section{Introduction}

The study of liturgical music in monastic institutions in the Nordic countries faces a great challenge: little is left of the medieval liturgical books. Only a few complete books have survived. As a rule, only a few pages, or even less, have remained of what once were codices of several hundred folios. They were made of parchment, a material much stronger than paper, and for that reason, many were taken apart, and the leaves were re-used as bindings for books or administrative accounts. These bindings, mostly dismantled but sometimes still attached to the documents they were supposed to protect, form the core of the fragment collections in the Northern countries and constitute the main research material for scholars interested in liturgical chant from the period before the Reformation.

In many cases it is not possible to decide where exactly the original codex was written or used. Often the contents are not of much help since many of the liturgical texts and chants were known all over Europe, and we have to look for saints or items that were particular to a certain place or area. Rarely these specific parts of the liturgy have survived, and we have to rely on other features, such as paleography or marginal notes, when trying to establish the primary provenance of a fragment.

To identify sources that might have been written or used in monastic institutions is therefore not an easy task. However, sometimes the contents of the fragments can be of help even if they consist of chants that were common for many areas, since the number and sequence of chants are not always the same in secular ${ }^{1}$ and monastic use. This is easily spotted in the Divine Office, where the chants of the three nocturns at matins ${ }^{2}$ on Sundays and feast days have the following order:
Matins
Secular use
1. nocturn
3 antiphons
3 responsories
2. nocturn
3 antiphons
3 responsories
3. nocturn
3 antiphons
3 responsories
Monastic use
6 antiphons
4 responsories
6 antiphons
4 responsories
1 antiphon
4 responsories

Unfortunately, many remains of the liturgical books containing chants from matins are so small that they do not have enough content to indicate whether they represent secular or monastic use. For that reason, we can assume that among the fragments in the Nordic 
countries are many more items that belonged to books from monastic institutions than the few that have been identified so far by their content. A more detailed investigation might result in finding more witnesses to monastic use, but for many fragments the question of whether they have monastic or secular provenance will have to remain open.

The present paper discusses sources in Iceland and Sweden where the content clearly indicates monastic origin. The main focus is on two fragmentary manuscripts containing part of an office for St Olav, i.e., chants to celebrate his feast day on 29 July. Here the mode of the liturgical chants is used to support a "reconstruction" of the whole office in a hypothetical monastic form that has not survived as a whole. In addition, two more monastic sources from Iceland are described, problematizing the issue of secondary provenance as a means to identify the original place of production or use of a manuscript.

\section{A Monastic Office for St Olav}

Among the few Latin fragments kept at the National Archives in Reykjavik is a double folio from a monastic antiphoner ${ }^{3}$ containing chants for the celebration for the patron saint of Norway, Olav. ${ }^{4}$ It can probably be dated to the 14th century. ${ }^{5}$ The fragment is cut in the outer margin of one of the pages, without any loss of text or music. The size of one leaf is $33.5 \times 24 \mathrm{~cm}$, the writing space $25 \times 17 \mathrm{~cm}$. There are 12 lines to the page. The musical notation is a square notation on four red lines. Both c-clef and f-clef are used. In addition, b-flat is used in three places, one of them in combination with the c-clef. The music scribe can well be the same person as the text scribe.

We do not know who wrote the manuscript or where it was written. In two places a note-sign typical for Icelandic liturgical manuscripts with music notation is used: a so-called double or twin note where two squares indicating the pitch are written so closely together (or even overlap) that they form one note head with two stems (see Figure 1a). Another detail that might point to Iceland as the place of origin is the use of a particular form of the letter e (see Figure 1b). ${ }^{6}$

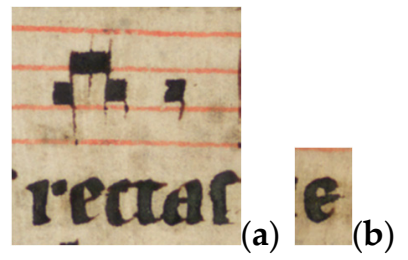

Figure 1. Details from National Archives, Reykjavik, Pjss "Antiphonarium 2": (a) Double note. (b) Uncial form of the letter $\mathbf{e}$.

The fragment seems to have been used as a cover for other documents, a common way of re-using parchment as described above. For that reason, the leaf has been folded in a new place, and part of the outer margin of folio 2 has been cut off, probably to fit the size of the document it was meant to protect. ${ }^{7}$

The content of the fragment is chants from matins for the office of St Olav for his natale on July 29:

$\begin{array}{ll}\text { Second nocturn: } \\ \text { MA11 } & \text { [Sancte martir olave te ... Icris nos expurges orationibus. Ps Exaudi deus orationem. } \\ \text { MA12 } & \text { Sancte martir olave domini preciose Ps Bonum est. } \\ \text { MR5 } & \text { Itaque devotissime V Jesu bone } \\ \text { MR6 } & \text { Confluebant ad baptisma V Confusi erant } \\ \text { MR7 } & \text { Florebat fides V Exultabat rex } \\ \text { MR8 } & \text { Justum deduxit V In mortalis est }\end{array}$


Third nocturn:

$\begin{array}{ll}\text { MAc } & \text { O beate pater olave } \\ \text { MR9 } & \text { Devenerat martir christi } V \text { Hij ergo collecto } \\ \text { MR10 } & \text { Egregius martir } V \text { In ammiratione } \\ \text { MR11 } & \text { Rex inclitus } V \text { Felici commercio } \\ \text { MR12 } & \text { Miles christi } V \text { Vt celestis regni sedem vale[amus] }\end{array}$

The number and sequence of chants shows clearly that the fragment follows the monastic cursus, with six (instead of three) antiphons for the second nocturn, and one (instead of three) antiphon for the third and last nocturn, in addition to four (instead of three) responsories for each of the two nocturns represented.

St Olav, king of Norway 1015-1028, was canonized in 1031, a year after his death in the Battle of Stiklestad. His cult became popular all over the Nordic countries, and the secular form of the proper office for St Olav has survived in many fragments from Scandinavia. ${ }^{8} \mathrm{~A}$ comparison with the Icelandic fragment reveals that the monastic form must be secondary to the secular office: in the Icelandic fragment the series of responsories has been augmented by adding items that are not proper for St Olav but have been used for other saints as well (MR8, MR12). If the monastic office had been the original composition from which the secular office had been arranged, one would have expected proper responsories also in the place of MR8 and MR12. ${ }^{9}$

The Olav's Office is not the only office where the secular form has been expanded to comply with the liturgical needs of a monastic institution. Similar adaptions from secular to monastic use can be found for other saints. One example is the office for St Augustine (Szendrei 2000). Here, too, the series of three times three responsories at matins have been augmented by adding three chants from the Common, one for each nocturn. However, they do not occupy the place of the fourth and last responsory, but are inserted between the second and third responsories, thus keeping one of the proper chants as the final responsory in each of the three nocturns "in order to avoid distorting the usual festive closing of each nocturn" (Szendrei 2000, p. 437).

A different approach can be found in the office tradition for St Maurice (Hankeln 2019). ${ }^{10}$ The secular series of nine responsories in a breviary with music notation from the diocese of Sitten in Switzerland can also be found in a source from France following the monastic cursus (Hankeln 2019, cf. Table 12 on page xlvii). Here, three responsories have been added at the end of the series to fill the gap. The first two nocturns each provide four of the chants also found at Sitten, whereas the third nocturn starts with the last responsory of the Sitten series followed by three responsories unknown to the Sitten breviary. ${ }^{11}$

The person, or persons, who adapted the secular form of the Olav's Office to the monastic form obviously had a range of different techniques to do this at their disposal, even if they chose to keep all items of the original office as they did. Firstly, they had to decide which responsories to use as a supplement to the already existing series for the night office. They had the choice of adding already existing chants, to set new texts to already existing melodies (as was done with many of the chants for the secular Olav's Office; see Østrem 2001 and Hankeln 2009), or to add completely new texts and melodies. Secondly, these additional chants could then be added in different ways to make up a series of 12 responsories, as, for instance, by placing the three new chants at the end of the series (Maurice), by adding one new chant to each nocturn but keeping the last responsory in its original place (Augustine), or by inserting a new chant at the end of each nocturn (Olav).

Celebrating a saint with chants from the repertory of items that could be used for a group of saints according to a category was a common way to find suitable liturgical items for new saints' feasts without a proper office written to honor this particular saint. Such chants were often collected in a separate section of liturgical books called Commune Sanctorum, the Common of the saints. ${ }^{12}$ The two known additional chants in the monastic office for Olav are taken from this part of the liturgy.

Miles christi with its verse Ut celestis is the responsory given in the printed Nidaros Breviary (BN 1519) from 1519 as the responsory for first vespers and as first choice for the ninth responsory at matins from the Common for one martyr (In natalico unius martyris). It 
appears in connection with Olav already in one of the 13th-century Icelandic manuscripts of the Nidaros ordinal. ${ }^{13}$ Miles christi is here prescribed as the responsory for first vespers for the feast of St Olav. ${ }^{14}$ The choice of Miles christi as the last responsory of matins seems thus to pick up on an already existing tradition to use this chant in connection with St Olav.

The other additional chant, Justum deduxit dominus/Immortalis est, is in BN prescribed as the responsory for first vespers, In natalico unius confessoris non pontificis, i.e., the Common for one confessor (not pope), and is (with the verse Magnificavit eum) also provided for martyrs. We can only guess what the third additional responsory might have been since the fragment has a lacuna for the responsories of the first nocturn where it would have had its place. Most likely it was taken from the Common as well.

A well-known aspect of offices from the late Middle Ages is that their chants often are ordered according to their modes (Hughes 1983). ${ }^{15}$ In many cases a systematic order of modes can be found regarding the antiphons of the prayer on the evening before the feast (first vespers), the antiphons and responsories of the Night office (matins), and the antiphons of the morning prayer (lauds). This is the case for the Olav's Office as well, and a look at the chant modes supports the argument that the secular form was primary to the monastic one. In the secular version the antiphons and responsories are arranged in the following modal order:

$\begin{array}{ll}\text { Secular } & \text { Modes } \\ \text { First vespers antiphons } & 1-4,8 \\ \text { Matins antiphons } & 1-8,1 \\ \text { Matins responsories } & 1-8,1 \\ \text { Lauds antiphons } & 1-5\end{array}$

Adding four antiphons from first vespers (VA2-VA5) at the end of the series at matins to increase the number of chants from nine $(3+3+3)$ to the required number of thirteen $(6+6+1)$ in the monastic version retains the order of modes, just moving the modal order from first vespers to matins. ${ }^{16}$ The insertion of one new responsory into each of the nocturns, on the other hand, disturbs the modal order of the responsory series:
Monastic
Modes $^{17}$
Matins antiphons
$1-8,1-4,8$
Matins responsories
$1-3, x, 4-6, x, 7,8,1, x$

Olav was amongst the most popular saints in Iceland according to the máldagar (Icelandic church inventories). Here he is ranked after Mary, together with Nicholas, Peter, and Porlákr (Cormack 1994, Figure 2 on page 29). There is no evidence that the adaption from the secular form of the office to a form suitable for monastic use took place in Iceland. On the other hand, no sources containing a monastic office for St Olav, the patron saint of Norway, have been found in Norwegian fragment collections so far. So where did the monastic version of the Olav's Office originate? In order to get closer to a possible answer, let us turn to Sweden.

\section{A Cistercian Source in Sweden}

Amongst the medieval fragments from liturgical books used as bindings for postreformational accounts at the National Archives in Stockholm, there are two leaves from a 15th-century monastic antiphoner with chants for St. Olav. ${ }^{18}$ The first leaf begins incompletely in the Magnificat antiphon of first vespers, Adest dies leticie laudes, and continues after the Invitatory antiphon, Magnus dominus et laudabilis, with chants from the first nocturn (antiphons 1-6 and responsories 1-2). The second leaf contains the last two responsories of matins, two antiphons for lauds, and the beginning of the antiphon for the first of the little hours (prime). Here are the preserved chants for matins: 
Fr 29710:

First nocturn:

MA1 Regnante illustrissimo rege olavo

MA2 Rex autem ille

MA3 Hic evangelice veritatis

MA4 Purificatus igitur

MA5 Consepultus christo

MA6 Cauebat uehementer

MR1 Jn regali fastigio $V$ Sordebat ei omnis

MR2 O quantus fidei (beginning only)

Fr 29711:

Third nocturn:

MR10 Egregius mar]tir olavus $V$ In ammiratione

MR11 Rex inclitus olavus $V$ Felice commercio

MR12 Miles christi $V$ Ut celestis regni/Gloria patri et filio

As it was the case for the Icelandic Olav's fragment, the number and sequence of the chants easily allow us to conclude that the fragment followed monastic use. The two manuscripts do not have much of their content in common, but both prescribe Miles christi with the verse Ut celestis as the last responsory of the third nocturn, preceded by responsory eight and nine from the secular form of the office. They agree thus with respect to supplementing the secular series of proper responsories with the same responsory from the Common in the same place. The Swedish source (Fr 29711) also provides the doxology (Gloria patri et filio) after the verse of the responsory. In the Icelandic fragment, Miles christi breaks off in the verse, and we do not know whether the doxology was present or not, but there is little reason to assume that it was omitted.

Regarding the antiphons, the two Swedish fragments are far more substantial than the Icelandic source with respect to the number they contain: the Magnificat antiphon for first vespers, the Invitatory antiphon, the six antiphons of the first nocturn, in addition to two antiphons for lauds, the Magnificat antiphon for second vespers, and the beginning of the antiphons for prime. The Icelandic fragment only contains the last two antiphons of the second nocturn, and the single antiphon for the third nocturn. However, even though they do not overlap, together they give us a good indication how this chant category was arranged for the monastic form of the office. For matins, the matins antiphons were used first (MA1-6 in the first nocturn, then MA7-9 in the second nocturn), and then four of the antiphons from first vesper were added (VA2-4 in the second nocturn to make up for the three missing items, and VA5 was used as the single antiphon in the third nocturn). The use of vesper antiphons $2-5$ at matins probably indicates that only one antiphon, super psalmos, was used for first vesper in the monastic version of the office. The use of the antiphons of lauds in the little hours is prescribed both in the Nidaros ordinary ${ }^{19}$ and in the printed breviary, i.e., the monastic form exemplified in the Icelandic fragment follows the secular office here. Whether this also goes for second vespers, where the lauds antiphons are used once more, we do not know since this part of the office has not survived in the fragments. For a schematic overview over the secular and reconstructed monastic form of the office and the contents of the fragments, see Table 1. 
Table 1. Overview over the chants in the Olav's Office ${ }^{20}$.

\begin{tabular}{|c|c|c|c|c|c|c|}
\hline & Secular Use & Mode & $\begin{array}{l}\text { Monastic Use } \\
\text { (Reconstructed) }\end{array}$ & Mode & $\begin{array}{l}\text { Reykjavik National } \\
\text { Archives Pjss } \\
\text { "Antiphonarium 2" }\end{array}$ & $\begin{array}{c}\text { Stockholm } \\
\text { National Archives } \\
\text { Fr29710+29711 }\end{array}$ \\
\hline \multirow[t]{7}{*}{ First vespers } & VA1 & 1 & VA [=VA1] & 1 & & \\
\hline & VA2 & 2 & & & & \\
\hline & VA3 & 3 & & & & \\
\hline & VA4 & 4 & & & & \\
\hline & VA5 & 8 & & & & \\
\hline & VR (variable) & & & & & \\
\hline & VAm & & VAm & & & VAm \\
\hline Matins & MI & & MI & & & MI \\
\hline \multirow[t]{10}{*}{ 1. nocturn } & MA1 & 1 & MA1 & 1 & & MA1 \\
\hline & MA2 & 2 & MA 2 & 2 & & MA2 \\
\hline & MA3 & 3 & MA 3 & 3 & & MA3 \\
\hline & & & MA 4 & 4 & & MA4 \\
\hline & & & MA 5 & 5 & & MA5 \\
\hline & & & MA 6 & 6 & & MA6 \\
\hline & MR1 & 1 & MR1 & 1 & & MR1 \\
\hline & MR2 & 2 & MR2 & 2 & & MR2 \\
\hline & MR3 & 3 & MR3 & 3 & & \\
\hline & & & MR4 from the Commor & & & \\
\hline \multirow[t]{10}{*}{ 2. nocturn } & MA4 & 4 & MA 7 & 7 & & \\
\hline & MA5 & 5 & MA 8 & 8 & & \\
\hline & MA6 & 6 & MA 9 & 1 & & \\
\hline & & & MA 10 [=VA2] & 2 & & \\
\hline & & & MA 11 [=VA3] & 3 & MA11 & \\
\hline & & & MA 12 [=VA4] & 4 & MA12 & \\
\hline & MR4 & 4 & MR5 [=MR4] & 4 & MR5 & \\
\hline & MR5 & 5 & MR6 [=MR5] & 5 & MR6 & \\
\hline & MR6 & 6 & MR7 [=MR6] & 6 & MR7 & \\
\hline & & & MR8 Justum deduxit & & MR8 Justum deduxit & \\
\hline \multirow[t]{7}{*}{ 3. nocturn } & MA7 & 7 & MAc [=VA5] & 8 & MAc & \\
\hline & MA8 & 8 & & & & \\
\hline & MA9 & 1 & & & & \\
\hline & MR7 & 7 & MR9 [=MR7] & 7 & MR9 & \\
\hline & MR8 & 8 & MR10 [=MR8] & 8 & MR10 & MR10 [=MR8] \\
\hline & MR9 & 1 & MR11 [=MR9] & 1 & MR11 & MR11 [=MR9] \\
\hline & & & MR12 Miles christi & & MR12 Miles christi & MR12 Miles christi \\
\hline
\end{tabular}


Table 1. Cont.

\begin{tabular}{|c|c|c|c|c|c|c|}
\hline & Secular Use & Mode & $\begin{array}{l}\text { Monastic Use } \\
\text { (Reconstructed) }\end{array}$ & Mode & $\begin{array}{l}\text { Reykjavik National } \\
\text { Archives Pjss } \\
\text { "Antiphonarium 2" }\end{array}$ & $\begin{array}{c}\text { Stockholm } \\
\text { National Archives } \\
\text { Fr29710+29711 }\end{array}$ \\
\hline \multirow[t]{6}{*}{ Lauds } & LA1 & 1 & LA [=LA1] & 1 & & LA \\
\hline & LA2 & 2 & & & & \\
\hline & LA3 & 3 & & & & \\
\hline & LA4 & 4 & & & & \\
\hline & LA5 & 5 & & & & \\
\hline & $\mathrm{LAb}$ & & $\mathrm{LAb}$ & & & $\mathrm{LAb}$ \\
\hline Prime & & & $\mathrm{PA}[=\mathrm{LA} 2]$ & 2 & & PA \\
\hline Terce & & & TA [=LA3] & 3 & & \\
\hline Sext & & & SA [=LA4] & 4 & & \\
\hline None & & & NA [=LA5] & 5 & & \\
\hline \multirow[t]{2}{*}{$\begin{array}{l}\text { Second } \\
\text { vespers }\end{array}$} & $\begin{array}{l}\text { ant. de } \\
\text { laudibus }\end{array}$ & & $?$ & & & \\
\hline & WAm & & WAm & & & \\
\hline
\end{tabular}

Four more fragments in the National Archives in Stockholm have been identified as belonging to the same codex as the two Olav's fragments. ${ }^{21}$ The MPO-database ${ }^{22}$ suggests Cistercian origin for the manuscript. ${ }^{23}$ In the first place, this might seem surprising as the Cistercian rite is known for its strict uniformity and reluctancy to give place to local traditions. However, feasts for local saints found their way into other Cistercian books in Sweden as well: both Birgitta, Elin of Skövde, and Sunniva appear in a 15th-century psalter, possibly from Gudsberga (Brunius 2013, p. 111). The reason for an office for St Olav to appear in a Cistercian book from Scandinavia can be traced to the Statutes from the Cistercian General Chapter. The edition by Joseph-Marie Canivez includes an entrance dated September 1237 which says that a petition from the abbots in Denmark, Sweden, and Norway to celebrate the feast day for St Olav with twelve lessons had been granted (Canivez 2010, p. 172). ${ }^{24}$ There seemed to have been a wish to honor the saint with the highest grading. ${ }^{25}$ Whether there already existed a monastic form of the Olav's Office that the Cistercians could make use of, we do not know. If only the secular office existed at that time, the adaption is likely to have taken place shortly after the positive response from the General Chapter in 1237 to meet the needs of the monastic communities.

All of the six Swedish fragments have a secondary provenance from Östergötland, i.e., they were used to bind administrative accounts from the Östergötland region. This suggests that the original book actually came from this area (Brunius 2013, p. 32, and personal communication). There were two prominent Cistercian institutions in Östergötland: Alvastra, founded in 1143 by monks from Clairveaux, and Vreta, a Benedictine nunnery from around 1110 that was turned into a Cistercian nunnery in $1162 .{ }^{26}$ Michael Gullick characterizes the source as a "good looking book with distinctive cadels-distinctive enough to identify other fragments if they exist-and perhaps the quality may point to Alvastra or Vreta". ${ }^{27}$ Perhaps a closer comparison with other codices known to have belonged to these institutions can confirm this tentative provenance.

\section{Other Monastic Antiphoners in Iceland}

The Cistercians never established themselves in Iceland, and we do not know how the monastic form of the Olav's Office found its way to Iceland. There were, on the other hand, five Benedictine foundations in Iceland in the Middle Ages: three monasteries (Pingeyrar (1133-1551), Munkapvera (1155-1551), Hítardalur (1166-1207)), and two nunneries (Kirkjubær (1186-1548), Reynistadur (1295-1551)). All of them will have had books 
containing the chants needed for the daily services. From the church inventories, we even know from some churches how many and what kind of books they owned at a certain time. However, we know very little about what happened to them after the Reformation, but the fragment from the National Archives in Reykjavik containing the chants for St. Olav might well once have been part of one of these lost books.

An investigation of the fragment collection in Iceland other than the National Archives shows that the Olav's fragment is not the only monastic manuscript among the fragmentary remains of medieval liturgical books in Iceland. One of the fragments kept at the National Library in Reykjavik, Lbs fragm 34, consists of a mutilated double folio from an antiphoner which has been used as book cover in the Northwest of Iceland. ${ }^{28}$ It has been cut in the margins, and part of the written space which originally consisted of 11 lines to the page has been lost. The contents are parts of the office for St Lucy: Folio 1 contains the chants from the Magnificat antiphon of first vespers (two syllables only) to the first responsory of matins (ends incompletely in the verse). Folio 2 begins incompletely in the second antiphon of lauds and ends with the Magnificat antiphon of second vespers. The series of six antiphons for the first nocturn show that it represents monastic use.

The fragment has been dated to the 15 th century, but was probably written earlier. ${ }^{29}$ The primary provenance is unknown, and nothing regarding the paleography or liturgical content suggests that the manuscript has been written by an Icelandic scribe. The use of D-clef is not very common in Icelandic fragments, either, and suggests a foreign origin as well. ${ }^{30}$ This does not exclude the scenario that the manuscript was written in Iceland by a person trained abroad, and it certainly does not mean that it has not been used in Iceland. Whether the presence of a possibly imported monastic manuscript indicates that there were not enough locally made books or rather is a witness to connections to monastic institutions outside of Iceland remains an open question.

Another monastic source has been described by Lilli Gjerløw in her publication on the Nidaros Antiphoner (Gjerløw 1979, pp. 259-61). ${ }^{31}$ It consists of four fragments representing five leaves of an antiphoner following monastic use. One of the fragments is kept at the National Library (Lbs fragm. 43); the other three belong to the National Museum and are kept at the Árni Magnússon Institute in Reykjavik (Pjms 194, 954, and 7437). Gjerløw dates them to the 14th to 15th century and suggests the bishopric of Hólar as the provenance of the book, based on the catalogue notes for two of the fragments (Lárusson 1963). ${ }^{32}$ However, only one of these can be connected to the Northern part of Iceland. ${ }^{33}$ Regarding the other one, Gjerløw probably confused the place name with a place of the same name in the North. ${ }^{34}$ According to the catalogue, the third fragment came to the National Museum from a book collector from the Northeast of Iceland. ${ }^{35}$ The fragment of the National Library was part of a private collection, the owner of which was born in the North of Iceland but lived most of his life in Reykjavik, and we do not know when and where he acquired the fragment. ${ }^{36}$ The manuscript certainly seems to have been written in Iceland. ${ }^{37}$ However, contrary to the situation in Sweden ${ }^{38}$, the secondary provenance of book fragments in Iceland is not a reliable indication for where exactly a fragment was written or where the original liturgical book was used. The fact that Lbs fragm. 34 ended up as binding for a book in the Westfjords of Iceland (belonging to the medieval bishopric of Skálholt), or that two of the fragments of the source by Gjerløw suggested as belonging to an institution under Hólar have a secondary provenance from the North-Eastern part of Iceland, should not be given too much attention. A study of paleographic features and a comparison with manuscripts with established provenance will probably give a more reliable result. ${ }^{39}$

\section{Conclusions}

The fragmentary state of many medieval liturgical books in the Nordic countries is a great challenge when trying to identify sources from monastic institutions. Sometimes the difference in order and selection of chants from matins in the Divine Office can help us to distinguish between sources from secular and monastic use. Several fragments in Icelandic collections can be assigned to monastic institutions due to this significant feature. 
Even if the secondary provenance of fragments from books with music notation in Iceland does not provide information that can help with relating them to a specific monastery, still the sources can give us a better picture of what was sung during the church services not only in the Icelandic institutions following monastic use but probably also in other Nordic countries. As shown above, the Olav's fragment provides interesting information about how this saint, venerated widely all over Scandinavia, was celebrated in monastic institutions in the later Middle Ages, and together with the Swedish fragments allows for the tentative reconstruction of a monastic form of the office. However, there are more sources to be studied more closely. An open eye for musical fragments indicating monastic use in all the Nordic archives and collections is thus of great value for gaining more knowledge about liturgical and musical traditions in monastic institutions of the North.

Funding: This research received no external funding.

Conflicts of Interest: The author declares no conflict of interest.

\section{Abbreviations}

1. Chants

$\begin{array}{ll}\text { A } & \text { Antiphon } \\ \text { Ac } & \text { First antiphon of the third nocturn in the monastic office } \\ \text { I } & \text { Invitatory antiphon } \\ \text { Ps } & \text { Psalm } \\ \text { R } & \text { Great responsory } \\ \text { V } & \text { Responsory verse } \\ \text { 2. Services } & \\ \text { V } & \text { First vespers } \\ \text { M } & \text { Matins } \\ \text { L } & \text { Lauds } \\ \text { V2 } & \text { Second Vespers } \\ \text { N } & \text { None } \\ \text { P } & \text { Prime } \\ \text { S } & \text { Sext } \\ \text { T } & \text { Terce } \\ \text { A number indicates which place within a service a chant occupies. } \\ \text { Example: } & \text { VA5 is the fifth antiphon at first vespers }\end{array}$

\section{Notes}

1 Secular use is the liturgy followed by non-monastic churches and institutions.

2 Matins, the night service of the office (or night office), is divided into three so-called nocturns.

3 An antiphoner is a book containing the chants for the Divine Office.

4 The fragment has the shelf mark Pjss "Antiphonarium 2". I encountered this fragment for the first time in the middle of the 1990s when working on my doctoral project on the Nidaros Antiphoner. It has also been included in Eyolf Østrem's doctoral dissertation (Østrem 2001, pp. 43-45). Due to COVID-19 restrictions, it has not been possible for me to work with either this or any of the other fragments presented in this paper other than by studying digital images.

5 I am grateful to Åslaug Ommundsen for her opinion on the dating, and for sharing her notes on the size of the fragment with me.

6 These and other particular features of Icelandic medieval Latin manuscripts have been discussed in Ommundsen and Attinger (2013).

7 On folio $1 \mathrm{r}$ - what once probably was the front page of the cover-there are some words in Latin added by a later hand:nominativo genitivo dativoaccusativo vocativoablativo [et/ex/est?] dualis casis in [atinyo?]I have not been able to make sense of the paragraph as a whole, but it starts with listing the Latin cases according to Donatus in Ars Minor (De nomine) (Gottskálk Jenssen, personal communication).

8 See Østrem (2001, pp. 239-62) for a list and description of the sources known to him and an introduction to the history of the office. It came into existence probably shortly after the erection of the archdiocese of Nidaros in 1152/3. Most of the fragments are from the 14th and 15th centuries.

9 Another argument for the monastic form being secondary is the order of the modes which will be discussed below. 
10 I am most grateful to Roman Hankeln for helpful comments on the matter and for kindly providing me with a copy of this publication.

11 A more complicated situation is encountered regarding the office for Louis IX of France: here a monastic office has been reworked into a secular form which then was taken as the point of departure for another monastic version (Gaposchkin 2009).

12 For a presentation of the early liturgy of St Olav, see for instance Iversen (2000).

13 For an edition of the Nidaros ordinal from these manuscripts, see Gjerløw (1968). Only ms B contains the feast of St Olav.

14 The other Icelandic source (written by the scribe Jón Porláksson in the 15th century: AM 241b III $\beta$ fol.) containing the responsory for first vespers of the Olav's Office provides O quantus fidei, i.e., the fragment does not follow the ordinal but agrees with the printed breviary which also has $O$ quantus fidei in this place.

15 In this article Andrew Hughes presents different modal schemes, and reflects on how the re-arrangement of modal orders might be used for working a way back to the original form of an office.

16 This rearranged order of the antiphons is not only based on the Icelandic fragment but also the Swedish source presented below.

$17 \mathrm{x}$ are placeholders for the modes of the added chants to illustrate where the order gets disturbed, independently of the actual modes of the chants.

18 Fr 29710 and Fr 29711. Images of Fr 29710 can be found on https:/ / sok.riksarkivet.se/bildvisning/R1029710_00001 (accessed on 27 April 2021). I am very grateful to the National Archives in Stockholm for providing me with images of Fr 29711.

19 "Super horas diurnales antiphone <de laudibus>" (Gjerløw 1968, p. 272).

20 Only modes for items relevant for showing the re-ordering of the modal order of the office are provided. When items have been moved to a new place, this is indicated by giving the original placement (in the secular office) of both antiphons and responsories in square brackets.

21 Fr 29712, Fr 644, Fr 9234, and Fr 29925. They contain chants for the feasts for Mary Magdalen, Lawrence, Simon and Jude, All Saints, Martin, and chants from the Temporale (the movable feasts of the liturgical year). More fragments of this codex can perhaps be found in the fragment collection.

22 Database of medieval book fragments at the National Archives in Stockholm (https:/ / sok.riksarkivet.se/mpo, accessed on 28 April 2021).

23 “Ord. Cist. auf Grund des Formulars, vgl. F. HUOT, L'Antiphonaire cistercien au XIIe siècle d'après les manuscrits de la Maigrauge, in: Zeitschrift für schweizerische Kirchengeschichte, 1971, Nr. 96, 127." (https:/ / sok.riksarkivet.se/MPO?FragmentID=644\& page=1\&postid=Mpo_644, accessed on 28 April 2021).

2421 Petitio abbatum Daciae, Suasciae, Norgeviae, de faciendo festo sancti Olani [sic] cum duodecim lectionibus in suis abbatiis tantum, exauditur.

25 On the other hand, the feast of St Olav never found its way into the official Cistercian calendar.

26 Vreta was the mother house of Askeby, a third Cistercian foundation in Östergötland.

27 Personal communication. Gullick also emphasizes that there is no reason why a good-looking book should not have been made for a parish church. For more reflections on this matter, see Gullick (2017).

“Voru utan um prófastsbók sr. Jóns Jónssonar og sr. Sigurðar Jónssonar í Holti í Önundarfirði”. For an image, see https: // handrit.is/en/manuscript/imaging/is/LbsFragm-0034 (accessed on 27 April 2021). The handwritten notes on the fragments of the National Library by Jakob Benediktsson have been published in Blöndal (1959).

29 14th century. Åslaug Ommundsen has been so kind as to have a look at this fragment and has suggested the earlier dating and a non-Icelandic provenance.

30 The D-clef is used in Copenhagen AM Access 7b HS 50 which certainly is Icelandic.

31 Gjerløw gives a detailed overview over the contents: parts of the Temporale (St John the evangelist, the octave of the Nativity, and Dominica in Quinquagesima) and Sanctorale (Agnes and Vincent) and traces the chants to other liturgical uses.

32 All information about the secondary provenance of the fragments from the National Museum given in this article is taken from this catalogue.

33 Pjms 7437: "Úr bandi á sálnaregistri Mývatnspinga 1785-1815". According to the catalogue, the fragment was moved to the National Museum from the National Archives on 27 March 1917.

34 Pjms 194: “Kom til Pjms. 26.9.1864 frá Birni Björnssyni bónda á Breiðabólstað á Álftanesi”. Another fragment, not connected to the antiphoner (Pjms 102), came to the National Museum on the same date. Here the former owner is called farmer á Bessastöðum which is the same area, located south of Reykjavik.

35 Pjms 954: “Kom til Pjms. 14/7 1873 frá Jónatan Porlákssyni á Pórðarstöðum” (1825-1906, cf. https:/ /handrit.is/en/biography/ view /JonTho020 (accessed on 27 April 2021)).

36 Lbs fragm. 43: Úr safni Valdimars Ásmundssonar (1852-1902, cf. https://handrit.is/en/biography/view/ValAsm001 (accessed on 27 April 2021)). See https:/ / handrit.is/en/manuscript/imaging/is/LbsFragm-0043 (accessed on 27 April 2021).

37 Gjerløw describes the greater initials covering a space over two lines as being "in the usual flowery style of late-medieval Icelandic manuscripts" (Gjerløw 1979, p. 259). The quality of the parchment and ink and the occasional occurrences of double notes (Pjms 7437) point in the same direction. Åslaug Ommundsen kindly confirmed Gjerløw's dating and provenance based on paleography (personal communication).

38 In Norway, too, the secondary provenance of fragments can-with some caution-be used to say something about the area of origin or use for the book that the fragments once were part of (for a discussion of this matter, see Pettersen (2013)). 
Sometimes decorations can provide clues s to a possible origin: a leaf from a gradual kept at the Árni Magnússon Institute in Reykjavik (AM Fasc.V 12, V), for instance, has been ascribed to Pingeyrarklaustur due to the figurative initial on the first page (Kristjánsdóttir 2016, pp. 271-72).

\section{References \\ Primary Sources}

Reykjavik, National Archives, Pjss "Antiphonarium 2".

Reykjavik, National Library, Lbs fragm. 34.

Reykjavik, National Library, Lbs fragm. 43.

Reykjavik, National Museum, Pjms 194, 954, and 7437.

Stockholm, National Archives, Fr 644, Fr 9234, Fr 29710, Fr 29711, Fr 29712 and Fr 29925.

\section{Secondary Sources}

Blöndal, Lárus H. 1959. Handritasafn Landsbókasafns: II. aukabindi. Reykjavík: Landsbókasafn Íslands.

BN. 1519. Breuiaria ad vsum ritumque sacrosancte Nidrosiensis ecclesie. Jam primum solerti optimorum artificum diligentia: Impensis vero ac mandatis insignibus longe reuerendi in Christo patris et domini, domini Erici Walkendorff, eiusdem ecclesie archiepiscopi dignissimi felix faustumque accipiunt exordium. Paris: Jean Kerbriant \& Jean Bienayse.

Brunius, Jan. 2013. From Manuscripts to Wrappers: Medieval Book Fragments in the Swedish National Archives. Vol. 35. Skrifter utgivna av Riksarkivet. Stockholm: Riksarkivet.

Canivez, Joseph-Marie. 2010. Statuta capitulorum generalium Ordinis Cisterciensis ab anno 1116 ad annum 1786: Opus in lineamentis ab eximio A. Trilhe non ita adumbratum suscepit. T. 2: Ab anno 1221 ad annum 1261. Vol. 10. Bibliothèque De La Reoue D'histoire Ecclésiastique. Louvain: Bureaux de la Revue.

Cormack, Margaret. 1994. The Saints in Iceland: Their Veneration from the Conversion to 1400. Vol. 78. Subsidia Hagiographica. Bruxelles: Société des Bollandistes.

Gaposchkin, Marianne Cecilia. 2009. The monastic office for Louis IX of France: Lauda Celestis Regio. Revue Mabillon 20: 55-86. [CrossRef]

Gjerløw, Lilli. 1968. Ordo Nidrosiensis ecclesiae (orðubók). Vol. 2. Libri liturgici provinciae Nidrosiensis medii aevi. Oslo: Universitetsforlaget.

Gjerløw, Lilli. 1979. Antiphonarium Nidrosiensis Ecclesiae. Vol. 3. Libri Liturgici Provinciae Nidrosiensis Medii Aevi. Oslo: Norsk Historisk Kjeldeskrift-Institutt, Den Rettshistoriske Kommisjon.

Gullick, Michael. 2017. Reflections on Nordic Latin fragment studies-Past and present-Together with three case studies. In Nordic Latin Manuscript Fragments: The Destruction and Reconstruction of Medieval Books. Edited by Åslaug Ommundsen and Tuomas Heikkilä. London: Routledge, pp. 24-65.

Hankeln, Roman. 2009. St. Olav's Augustine-responsories: Contrafactum technique and political message. In Political Plainchant? Music, Text and Historical Context of Medieval Saints' Offices. Vol. 91. Wissenschaftliche Abhandlungen. Edited by Roman Hankeln. Ottawa: Institute of Mediaeval Music, pp. 171-99.

Hankeln, Roman. 2019. Officium sancti Mauritii sociorumque eius Thebaicae legionis (traditione Sedunensis ecclesiae). Vol. 65/30. Wissenschaftliche Abhandlungen. Kitchener: Institute of Mediaeval Music.

Hughes, Andrew. 1983. Modal order and disorder in the rhymed office. Musica Disciplina 37: 29-51. Available online: http: //www.jstor.org/stable/20532256 (accessed on 27 April 2021).

Iversen, Gunilla. 2000. Transforming a Viking into a saint. The Divine Office of St. Olav. In The Divine Office in the Latin Middle Ages: Methodology and Source Studies, Regional Developments, Hagiography: Written in Honor of Professor Ruth Steiner. Edited by Margot Fassler and Rebecca A. Baltzer. Oxford: Oxford University Press, pp. 401-29.

Kristjánsdóttir, Guðbjörg. 2016. Handritalýsingar í benediktínaklaustrinu á Pingeyrum. In Íslensk klausturmenning á miðöldum. Edited by Haraldur Bernharðsson. Reykjavík: Háskólaútgáfan, pp. 227-311.

Lárusson, Magnús Már. 1963. Skinnhandrit í Pjóðminjasafni Îslands. Unpublished typescript.

Ommundsen, Åslaug, and Gisela Attinger. 2013. Icelandic liturgical books and how to recognise them. Scriptorium 67: 293-317, plates 1-42.

Østrem, Eyolf. 2001. The Office of Saint Olav: A Study in Chant Transmission. Vol. 18. Studia Musicologica Upsaliensia. Uppsala: Acta Universitatis Upsaliensis.

Pettersen, Gunnar I. 2013. From parchments books to fragments: Norwegian medieval codices before and after the Reformation. In Latin Manuscripts of Medieval Norway: Studies in Memory of Lilli Gjerløw. Vol. 5. Nota Bene. Edited by Espen Karlsen. Oslo: Novus Press.

Szendrei, Janka. 2000. On the prose historia of St. Augustine. In The Divine Office in the Latin Middle Ages: Methodology and Source Studies, Regional Developments, Hagiography: Written in Honor of Professor Ruth Steiner. Edited by Margot Fassler and Rebecca A. Baltzer. Oxford: Oxford University Press, pp. 430-42. 